FORUM

\title{
Our 1980s
}

\author{
Edited by
}

Don Kalb 
This Focaal symposium on 1989 is organized by Don Kalb. Earlier versions of the papers by Greskovitch, Holmes, Kalb and Ost were presented at the 1989 commemorative conference of the Einaudi Center for European Studies, Cornell University. We are grateful to Dr. Holly Case for allowing Focaal to use this material as the basis for this Forum. We were delighted with the enthusiasm with which Michael Burawoy, Caroline Humphrey, and Katherine Verdery were willing to contribute their own thoughts on short notice. 


\title{
My long 1989: Anticipations of a new Europe
}

\author{
Douglas R. Holmes
}

\section{Friuli}

Interviews with the leadership of the Movimento Friuli (MF) were the last task, almost a postscript, of a study that preoccupied me during the 1980s. After a decade of research in the Friuli region of northeast Italy I was reasonably satisfied that I had achieved something like closure on the project. I was reluctant in the summer of 1987 to open any new lines of inquiry that might disturb my contentment. So I pursued a final series of interviews basically as a courtesy to a friend who had coaxed me along on what became a series of propitious encounters. During these meetings I first heard talk of a curious vision of nationhood that transformed the way I conceptualized Europe. One interview was decisive.

I met Marco De Agostini, general secretary of the MF, and his wife in a cafe in Tricesimo. The interview began with a brief history of the Movimento Friuli and its founding in the late 1960s out of student demands for the creation of a university in Udine. The efforts of clerics and intellectuals, committed to linguistic and cultural preservation, were prominent in the founding of the party. De Agostini described the spirit of the movement as neither a party of the right nor of the left, but as an avant-garde; a party of ideas. He talked about the Catholic roots of the MF and the "mythical socialism" that informed this political imaginary.

He also portrayed the illiberal side to the MF vision, one oriented toward establishing special rights and privileges for those who are judged ethnically Friulian; specifically, the imposition of discriminatory preference in employment of civil servants favoring Friulani by requiring a minimum five-year residence before appointment to government positions. The purpose, which was openly expressed, was to exclude southern Italians from government bureaus. There was also preoccupation with redrawing borders of eastern Friuli through urban neighborhoods of Gorizia, dividing what were believed to be Slavic- and Friulian-speaking districts.

The quixotic political narrative was broken when De Agostini asserted the aspiration of the MF for Friulian autonomy. "We are Europeanistic. ... Borders are political not cultural." He described the goal of a Friulian "nation" as European, but at the same time, independent of any state. The European Community was seen as the supranational context in which the movement could achieve its autonomous aspirations. Embedding ethnic autonomy within a European context-rendering the Italian nation-state largely irrelevant-represented a striking conceptualization of community and polity. The aspirations that informed this vision were at odds with the trajectory of Western European political developments in the late 1980s still under the thrall of the post-World War II political order. Rather, it hinted at a new political discourse on Europe; one unhinged from the civic imperatives of the nation-state. After this late summer 
encounter I turned my attention-my full attention-to European integration.

\section{Strasbourg}

In the spring and summer of 1989, the last moves of the cold war were unfolding, the two hundredth anniversary of the storming of the Bastille was commemorated, democracy protests in Tiananmen Square were brutally quashed, and tourists surged through Strasbourg. I was staying in a hotel on the south bank of the L'Ill just below the great locks, which regulate the level of water as it flows around the city and into the Rhine. On most days I took a bus away from the center city past the university to the European Quarter, setting of the modernist Palais d'Europe that houses the Council of Europe and the European Parliament. It was the latter institution that I was there to study.

At that time the European Parliament was a little known and a little understood institution moving between Brussels and Strasbourg, operating ostensibly as the consultative body of the European Community, yet lacking any real political power. In June 1989 a parliamentary election was scheduled. I was in Strasbourg to observe the campaign because I thought it might provide insights into the emerging politics of European integration. Integration was poised to accelerate in the wake of the passage of the Single European Act (SEA), which legislated the establishment of a single market among the then twelve member states of the Community. It was clear, however, that market integration presaged a far more sweeping political project aimed at the creation of a new type of polity, a European Union.

I spent much of my time across the street from offices of the parliament in the splendid Parc de l'Orangerie. Each day I took with me to a bench under a stand of pine trees, copies of the treaties that serve as the constitutional instruments of the European Community as well as the official reports and documents of the parliament pertaining to the technical require- ments of creating the single market. In a garden designed by Louis XIV's landscape architect, André Le Nôtre, I became familiar with the arcane project of European integration.

I also followed press accounts of a two-day meeting in Madrid of the European Council on 26 and 27 June, during which a proposal tabled by the governors of the central banks of the twelve member states of the EC under the direction of Jacques Delors, president of the European Commission, was considered. The proposal, known as the "Delors Plan," called for the convening of an Intergovernmental Conference (IGC) that would draft revisions to the Treaty of Rome and subsequent treaties to make possible European Monetary Union (EMU). The plan was approved. In the ensuing months, however, the fall of the Berlin Wall dramatically recast this priority. The German government argued that monetary union must be pursued in concert with further political integration. At a subsequent meeting the following year in Dublin, the European Council acceded to the German demands and called a second IGC to consider simultaneously this expanded agenda of political integration. The work of the two IGCs yielded documents that became the basis of the Maastricht Treaty on European Union.

It was in retrospect an eerie episode of research. The constitutional documents that I read anticipated changes in the contours of Europe looming, though barely imaginable, in the spring and summer of 1989. I also became aware of two other activist agendas. I heard for the first time reference to a series of concepts drawn from Catholic Social Doctrine-encompassed by the term subsidiarity-that framed a theory of federalism, a European federalism. These Catholic concepts imparted a distinctive architecture of and for an expanding Europe. I also became aware of a small political movement in France, the Front national, led by the mercurial figure of Jean-Marie Le Pen, which espoused an agenda at odds with the project of European integration. At that time, however, I did not yet fully grasp the capacity of M. Le Pen's insurgency to define the principles of an emphatically illiberal Europe. 


\section{Zaborów}

My invitation to participate in a conference that took place in early October 1990 in yellow villa in Zaborów, Poland was an afterthought. I was a last-minute substitute for someone better suited to address the theme of the gathering, "The anthropology of politics in post-communist societies." I am pretty sure I was the only person in attendance whose work was entirely centered in Western Europe. But I doubt there was anyone more fascinated with the conference and its thirty-five or so participants than I was.

Janine Wedel did a superb job organizing the conference; Katherine Verdery and Ernest Gellner guided the sessions. Verdery demonstrated remarkable agility at negotiating the very significant differences in experience of 1989 among participants. She was sensitive to the fact that every participant was renegotiating fundamental contingencies of their lives and not merely their intellectual careers. She imparted a generosity that allowed the stories to unfold without rancor or recrimination. Gellner by contrast provided a moody gravitas to the discussions as he sought to lend historical perspective to events while interleaving his own rich biographical reflections. He seemed intent on restraining excess enthusiasm insinuating the possibility that things could still turn out badly.

The papers sought for the most part to address the issue of the post-communist Europe by way of first hand, ethnographic narratives recounting the exhilarating events that were continuing to transpire, and particularly the political and intellectual activisms that were shaping new regimes. Not surprising, the Polish participants had the most unified, if not triumphal, rendering of this intensely lived history. The Romanian scholars, by contrast, were more guarded.

For me, as something of an outsider, there were striking details. On the one hand, there were poignant examples of how a space for anthropology had been courageously nurtured by a number of these scholars using mere fragments of publications dating from the 1920s and 1930s. On the other hand, there were presentations by a sprinkling of senior scholars who remained in denial of what was unfolding around them. They articulated a stunningly opaque scholarship, still aligned with the intellectual thuggery of recently eclipsed regimes.

The conference came to a close on 3 October and a small group of about dozen or so participants spent the night at the yellow villa. After dinner we gathered around a small, by today's standards a miniscule, television and watched the ceremonies and celebrations marking German Reunification. We spoke little. Gellner seemed troubled, almost vexed, by what we were watching that night. I read his mood as ambivalent. I am almost convince that was a misreading.

$\mathrm{He}$ and the rest of us were witnessing something that was in many respects unthinkable and we were bereft of metaphors to capture its significant analytically or emotionally. We watched the transformation of that thing we call "Germany," that thing that had so profoundly shaped all of our lives. We were deeply implicated in the celebration in ways that were difficult, painfully difficult, to reconcile with our personal histories. And this was, perhaps, most true of Gellner. We lingered for a while after the broadcast ended and then Gellner suggested we sing something to punctuate the evening. We sang, rather softly, L'Internationale.

I was more restless than reflective that evening. I knew that the documents defining the European project that I read in Strasbourg had, in fact, anticipated something like the events that we were witnessing. I was, moreover, convinced that those texts would serve as instruments for shaping the Europe that was in the making. I also knew that the cultural demiurges I first encountered in Friuli were not aberrations, but integral to what would become the new Europe. It would, however, have been tactless to broach these insights late that evening.

Douglas R. Holmes teaches anthropology at the State University of New York at Binghamton. His current research examines how five central banks underwrite representations of the future with faith and credit.

E-mail: dholmes@binghamton.edu. 